\title{
Columbus's First Voyage: Profit Or Loss From A Historical Accountant's Perspective
}

\author{
David Satava, (E-mail: satavad@uhv.edu), University of Houston, Victoria
}

\begin{abstract}
Determining the cost of Columbus's first voyage to the new world is very difficult to do with any degree of accuracy. The primary reasons for this is that the complete set of records does not exist and may not have ever existed. As a result, scholars have proposed a wide variety of figures supposedly representing the costs of Columbus's first voyage. Because of the conflicting information associated with this voyage, a three-step decision-making model approach was developed and used when deciding between conflicting accounting figures. In addition, several historical events, such as the sinking of the Santa Maria and the lifetime finder's fee annuity for being the first to spot land in the new world was reviewed for their possible effect on the accounting for this voyage. Overall, the purpose of this paper is to prepare a pro-forma financial statement in order to determine whether or not Columbus's first voyage was profitable or not.
\end{abstract}

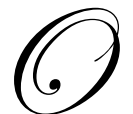

n August 3, 1492, Christopher Columbus set sail with three ships and some 90 men to search for a trade route to the West Indies. Instead, he found San Salvador, Cuba, and the North American continent. When he returned to Spain seven months later, he brought back some exotic birds, small amounts of gold, slaves, and other miscellaneous items. Yet, while what Columbus brought back was somewhat insignificant, the potential for future riches so excited the monarchs of Spain that they promptly sent Columbus back with 17 ships and over 1,200 people to find vast treasures of gold.

Over the years, scholars have proposed a wide variety of estimates about the cost in terms of modern currency of the first voyage to the new world. (Pickering, 2000). A number of difficulties arise when trying to convert a five-hundred-year-old currency into today's dollar. First, the maravedis, the currency used in Columbus's day has not existed for hundreds of years. Second, the United States came into existence after the expiration of the maravedis, which makes it difficult to determine an appropriate exchange rate since the two currencies never coexisted at the same time. Third, during the past five hundred years, the prices of gold, wages, food, goods and services, etc. have not kept the same relative relationship to one another. Fourth, the world has greatly changed during this time, especially with respect to technology: Trying to figure the cost of sailing a wooden ship in times when ocean liners carry over three thousand passengers at a time is an anachronism and may have little relevance in today's world.

Thus, the wide diversity of conflicting estimates that scholars have offered for the cost of the first voyage in current dollars is understandable. In order to reduce the problems associated with translating a five hundred year old currency into modern values and to reduce the wide variety of modern currency estimates scholars have suggested, the historical cost method has been selected for use in the remainder of this paper. Other problems are encountered when trying to determine the cost of the first voyage. According to Thacher (1903), the complete original accounting records do not exist. While there was a comptroller on board, Rodrigo Sanchez, there is no record that he ever prepared a profit and loss statement for the first voyage for public consumption (Fusion, 1987). Phillips and Phillips (1992) conclude that it is impossible to reconstruct all of the transactions for this voyage. Davidson (1997) contends that understanding the financing of the first voyage of Columbus is perplexing.

The lack of original accounting records has made it difficult for scholars to agree upon how much the monarchs actually contributed to the first voyage, let alone what the first voyage cost in current historical terms. As a result, scholars have suggested a wide range of numbers with respect to the historical cost of the first voyage. 
Because of the conflicting accounting figures associated with the historical cost of Columbus's first voyage and in order to prepare a fairly reliable pro-forma financial statement, it was necessary to develop a three-step resolution approach in order to resolve conflicting figures.

\section{RESOLUTION APPROACH TO CONTRADICTORY INFORMATION}

One of the major problems in preparing a pro-forma financial statement for an activity that occurred fivehundred years ago is accurately selecting from among contradictory financial information, especially since very few original accounting documents exist today. In order to choose from among contradictory scholarly interpretations, it was necessary to develop a decision-making approach for selecting reliable accounting information. This approach is consistent with forensic accounting techniques, which originally arose from a need to reconstruct business transactions occurring from fraud, fire, or sabotage, etc. (Martin, 1998). These techniques can also be used to re-create pro-forma financial statements, such as for Columbus's first voyage.

The following three-step hierarchical decision model was used in selecting the final figures for preparing the pro-forma balance sheet and pro-forma income statement. First, where a written contract exists, that written contract was used to decide between contradictory information. Second, when written documentation did not exist, then various forensic accounting techniques, such as analysis of industry data, reasonableness tests, and comparisons with the customs of the day were utilized. Last, when the first two steps were not available, useful, or relevant, the convention of conservatism was used. Conservatism requires the accountant to select those figures that result in the lowest revenue or highest expense when two or more alternatives exist. Thus, conservatism results in the lowest possible net income or highest loss being reported

The purpose of this paper is to determine whether or not Columbus's first voyage to the new world showed a profit or not based on historical cost. Using historical cost instead of translating historical costs to a modern value should reduce the wide variety of figures that have been promulgated over the years by scholars. Overall, creating a pro-forma financial statement for Columbus's first voyage will involve evaluating a diversity of accounting figures for reasonableness and using a "resolution approach" to contradictory accounting information. Furthermore, in evaluating whether Columbus's first voyage lost money or not, several historical events that have been overlooked by scholars and may have a significant affect on the accounting records will also be evaluated.

\section{ORGANIZATION OF PAPER}

The organization of the remainder of this paper is as follows. First, the contractual agreement between the king Ferdinand and queen Isabella of Spain and Columbus will be discussed, as it affects the preparation of the proforma financial statements of this joint venture. Second, the history of the accountants' role in the financing of the first voyage of Columbus will be described in order to obtain insight and appreciation for their contribution in helping to provide the funds necessary to make this voyage possible. Third, how much the king and queen of Spain and Columbus may have advanced for the first voyage will be reviewed as it serves to determine the maximum spent by Columbus on this voyage. Fourth, key overlooked historical events that may affect the accounting for the first voyage, like the sinking of the Santa Maria will be reviewed as they affect the financial statements. Fifth, a pro-forma income statement and pro-forma balance sheet will be prepared for analysis. Last, an analysis of the pro-forma income statement will be reviewed to determine whether the first voyage was profitable or not.

\section{THE CONTRACT}

In January 1492, after six years of deliberating and delaying, the king and queen of Spain finally agreed to finance Columbus's first voyage. That is, they did until they heard his demands: 1 . Columbus wanted titles and the riches associated with those titles. The royals in frustration dismissed Columbus for what was supposed to be the "last" time because they did not want to give him the titles of Don, and Admiral of the Ocean Sea, and Viceroy and Governor General. Along with that they did not initially want to grant Columbus the wealth associated with the titles and the 10 percent of the profits for each voyage that he wanted. The royals relented after several treasurers persuaded Queen Isabella to support the voyage (See Accountants to the Rescue below). The contract between the 
king and queen of Spain and Christopher Columbus was eventually signed and notarized on April 17, 1492 (Thacher, 1903; Granzotto, 1985). The contract often referred to by scholars as the "capitulations" is five paragraphs in length (Granzotto, 1985) and is summarized below. The benefits of the contract which accrue to Columbus are summarized as follows:

1. Given title of Don and Admiral of the Ocean Sea for life and to be passed on to his heirs.

2. Given title of Viceroy and Governor General for all land and islands discovered on trip

3. Received a 10 percent commission on all commerce including pearls, precious stones, gold, silver, spices, and any other kind of merchandise bought and sold within the confines of the new admiralty

4. $\quad$ Made the final judge if there are any disputes arising in his admiralty

5. Could, at his discretion, invest up to 12.5 percent of the total expenditures of a trip and in return receive up to 12.5 percent of the profits.

This contract is one of the best tools available to the forensic accountant in determining the costs of the first voyage because it represents an agreement between the monarchs and Columbus, whose differing issues that took three-months of negotiations to resolve. According to Martin (1998) the basic premise behind forensic accounting is that all figures are suspect until proven otherwise. Thus, supporting or corroborating information is critical in the process. Therefore, whenever discrepancies in the historical record regarding the costs of Columbus's first voyage were identified, the contract was reviewed first and foremost to clarify any material differences. Since the contract took over three months to write and get signed, it is presumed that the parties to the contract took great care in the use of the words used to express their agreement.

The contract will be used in this paper to resolve issues such as the question of the actual amount Columbus contributed to the first voyage. For example, according to Las Casas (1951), a priest and contemporary of Columbus, the crown advanced 1,000,000 maravedis and Columbus contributed 500,000 maravedis to the venture. These figures place Columbus's contribution at 33 percent of the total and are significantly higher than the what is specified in the contract (12.5 percent). Even though Las Casas was a contemporary of Columbus and had access to Columbus's daily $\log$ and other documents, the contract will be used to determine the maximum amount that Columbus contributed. Even though Columbus's last will and testament states that he put up 500,000 maravedis (Davidson, 1997), the contract is clear in this matter and will be used to limit Columbus's contribution to 12.5 percent of the crowns contribution since it and not the will was signed and agreed to by the king and queen of Spain. Furthermore, it is not reasonable to believe that Columbus would contribute more funds (33 percent minus 12.5 percent) to a joint venture, knowing in advance that he would not be able to share in the profits from those additional contributions.

\section{ACCOUNTANTS TO THE RESCUE: WHERE DID THE CROWN'S MONEY COME FROM?}

According to Phillips and Phillips (1992), in January, 1492, after hearing Columbus's demands, the queen of Spain dismissed Columbus for the "last" time. Many in the court thought Columbus's demands were excessive, especially since he had been refused financing for the past six years. However, after Columbus departed, Luis de Santangel, personal treasurer to the king and treasurer of the Santa Hermandad (a Spanish national organization supervising the rural militia); along with Quintanilla, controller of the Castilian finance and others went in to see the queen. They persuaded her to support Columbus by noting that in order to become the greatest queen in Christendom, she should agree to Columbus's terms. Santangel pointed out, that from a cash flow perspective, there was no cost to the crown for giving titles, and that the crown would not be required to pay anything to Columbus until he, Columbus, actually found something of value.

The queen expressed concern that the royal coffers were quite low because of the recent war with the Moors, and maybe the voyage should be delayed until a later date. Santangel informed the queen that he could find the funds and would loan them to the monarchs to finance their portion of the capital contributions (Davidson, 1997; Granzotto, 1985). As treasurer of the Santa Hermandad, Santangel was aware that it had excess funds, which could be loaned out. With the help of Talavera, joint treasurer of the San Hermandad, and Quintanilla, money was borrowed from the Santa Hermandad and used to cover the monarchs' capital contributions for the first voyage. Later, the Hermandad 
was reimbursed from other governmental funds. Phillips and Phillips (1992) further note that deficit financing and creative accounting were not invented in the twentieth-century.

While some scholars (Laufer, 1986; Phillips and Phillips, 1992; and Davidson, 1997) claim the queen was willing to pawn her jewels to finance the trip, she never had to actually put them up for collateral. In fact, other scholars believe that the jewels were already pawned in order to secure financing for the war with the Moors (Davidson, 1997; Dyson 1991). If already pawned, they could not be offered to help finance Columbus's voyage. One reason Santangel was willing to borrow money to cover the royals' share of the capital needed to finance the first voyage was that he, Santangel, believed that the estimated cost of the first voyage was small, no more than the cost of supporting the royals for a week. He further believed that the potential for profits was far greater than the voyages estimated costs (Tirado, 2001). Fusion (1987) notes that Spain received a return on investment of over 1,733,000 maravedis for every maravedis that was eventually invested by the Spanish monarchs.

\section{HOW MUCH WAS ADVANCED BY THE CROWN FOR THE FIRST VOYAGE?}

As far as the records indicate, no profit and loss statement was prepared for the first voyage during that time, nor does one seem to currently exist. The nearest person to an accountant on the first voyage was the comptroller, Rodrigo Sanchez, who was the brother of Gabriel Sanchez, the royal treasurer. Sanchez's primary job was to make sure that the royals received their fair share of the treasures found on the trip and that Columbus only made legitimate expenditures (Jane, 1960). Because of the lack of a financial statement, scholars disagree on exactly how much the monarchs contributed to the first voyage (Tirado, 2001; Davidson, 1997; Phillips and Phillips, 1992; and Dyson, 1991). Since Columbus could only spend what was contributed to the joint venture, being able to determine the amount initially authorized and or advanced by the crown will help tremendously in identifying the total expenses that could be expended for the first voyage to the new world.

There is, unfortunately, some discussion among scholars about the amount of funding the monarchs actually advanced to Columbus. Helps (1910) and Wolcott (1992) believe that Santangel advanced 1,140,000 maravedis to Columbus. Wolcott believes that a promissory note dated May 2, 1492, indicates the monarchs may have borrowed $1,140,000$ from the Santa Hermandad. Wolcott was not sure if 140,000 of the 1,140,000 maravedis were for additional general expenses or for interest on the loan. Phillips and Phillips (1992) indicate, however, that 1,140,000 maravedis was the amount repaid to the Hermandad. Dyson (1991) notes that Santangel advanced 1,140,000 maravedis from the Hermandad to the crown, at $14 \%$ interest for two years.

Las Casas (1500s; translated by Collard, 1953) notes that the royals initially contributed 1,000,000 maravedis. According to Hale (1891), the expense to the crown amounted to 1,140,000 maravedis. Kayserling indicates that 1,140,000 maravedis were advanced to Columbus on May 5, 1492 for general expenses, wages, and wages for Columbus. Davidson (1997) believes that the loan was repaid to Santangel on May 5, 1492. Since the contract was signed on April 17, 1492, (Thacher, 1903; Granzotto, 1985), and Columbus left for Palos on May 12, 1492 (Dyson, 1991), and the crown's resources were quite limited after the war with the Moors, it is unlikely that the crown was able to pay off the loan so quickly. Overall, what may have happened is that more than one governmental agency was used to float the money until the Santa Hermandad was eventually paid off sometime during 1493. Kayserling believes, after reviewing financial documents available to him, that the money was paid back on May 20, 1493. Some scholars contend that it was later in 1493. No wonder Davidson comments that the manner of financing Columbus's first voyage can best be called "perplexing."

Whether 1,000,000 maravedis was initially advanced and 1,140,00 repaid or 1,140,000 was initially advanced and repaid does not change the fact that 1,140,000 is the most agreed-upon figure with respect to what was repaid by the crown to the Hermandad. It does appear that a number of quasi-governmental agencies were involved in financing Columbus's first voyage. Overall, the disagreement among scholars has probably occurred because the loan and repayment seemed to have moved around through a number of quasi-governmental accounts and seems to have been handled by a number of officials. This transaction truly indicates that the term "creative accounting" was understood five hundred years ago. 
Overall, the two most quoted figures regarding how much the royals contributed to the joint venture to the new world is $1,000,000$ and $1,140,000)$ maravedis. The main question appears to be whether the difference of 140,000 maravedis is for interest charges, wages to Columbus, or an additional amount needed to cover additional general expenses. Based on the contract it appears that Columbus was not entitled to a wage because he was to share in 10 percent of the profits and in additional profit-sharing if he contributed up 12.5 percent of the cost of the voyage. It is unlikely that this loan was an interest free loan as the royals, like everyone else at the time, paid interest when they borrowed money. This would be especially true because the queen had noted in January 1492 that the coffers were low. It is unlikely that all of the various agencies involved with this transaction would loan money for free. Furthermore, even if it were an interest free loan, generally accepted accounting principles would require that an imputed interest rate be used.

An imputed interest rate situation occurs when the initial amount borrowed is the same amount that is paid back at a later date. The accounting profession holds that an interest rate is implied in this situation and, therefore, one should be imputed. Determining an imputed interest amount is difficult with respect to Columbus's first voyage because it seems that there were many times that much money floated between the various quasi-governmental accounts. For example, Thacher (1903) states that the loan for 1,000,000 maravedis was made in the spring of 1492 and that 1,140,000 maravedis was repaid to the Santa Hermandad in the fall of 1493. At twenty-one months, this would represent an interest rate of 8 percent. Using an imputed interest rate of $8 \%$ for this period of time would significantly reduce the $1,140,000$ maravedis payments to the Hermandad to $1,000,000$ maravedis as the amount initially loaned to the crown. What is not known is the rate of the loan and the exact time period the money was loaned.

What seems plausible is that Santangel borrowed 1,000,000 maravedis from the Santa Hermandad and then, sometime in 1493, repaid them 1,140,000 maravedis. Overall, it appears likely that the monarchs had to borrow money, with interest, since their coffers were empty after the war with the Moors. It appears reasonable that the amount loaned to the monarchs, which was then contributed to the first voyage, is $1,000,000$ maravedis. This amount is confirmed in Columbus's last will and testament where he states that the Crown did not want to give more than 1,000,000 maravedis to the voyage (Taviani, 1974. Landstrom (1966) supports this amount noting that Santangel initially borrowed 1,000,000 maravedis.

Since the contract does not discuss how or where each participant to the joint venture raised his or her portion, the financial statements will not need to include any interest the monarchs and or Columbus needed in order to raise their portions of the venture capital for the first voyage. Thus, the 140,000 maravedis will be assumed to be an interest obligation for the monarchs and not an expense to the joint venture. The same holds true for Columbus's venture capital, as a number of scholars have speculated that Columbus would have had to borrow money for this share. Thus, the initial contribution by the monarchs will be set at one million maravedis. Later in this paper, this amount will be used as the starting point for determining the reasonableness of the total expenses of the first voyage (Exhibits $1 \& 2$ ).

\section{COLUMBUS'S CONTRIBUTION - WHERE DID IT COME FROM?}

According to the contract, Columbus was permitted to contribute up to 12.5 percent of the costs of the voyage in order to be entitled to 12.5 percent of the profits. Columbus did not have much money prior to the voyage. For years he was dependent upon the queen for living expenses and monies earned from map making. For example, when Columbus met with the queen in January 1492, she authorized the treasurer to send him 20,000 maravedis for traveling expenses and for suitable clothing. Scholars indicate that Columbus would have had to borrow money in order to put in for a 12.5 percent stake of the profits. It is not known for sure from whom Columbus obtained his stake in the joint venture. Because the first voyage is being treated as a joint venture, it is not necessary to determine where or how Columbus obtained his money, or for that matter, where or how the monarchs obtained theirs. It is only necessary that Columbus's 12.5 percent be calculated based on the monarchs' contribution excluding the cost of borrowing (since the cost of borrowing capital is not mentioned in the contract). 


\section{HOW MUCH WAS THE TOTAL CONTRIBUTED TO THE JOINT VENTURE?}

At this point we have identified the crown's contribution at 1,000,000 maravedis and that Columbus, based on the contract, would be permitted to contribute up to 12.5 percent of the first voyage's expenses for up to 12.5 percent of the profits.. Before Columbus's contribution can be calculated, a number of issues have to be resolved. First, while the Santa Maria was leased from its owner, the two other ships (Pinta and Nina) were conscripted from the city of Palos for s penalty for past sea crimes. The fair value of these two ships will have to be determined in order to calculate the total amount contributed by the crown. In addition, a number of historical events were overlooked by historians that may increase the amount of the total contribution to the first voyage to the new world. For example, the crown promised a lifetime annuity to the first person who spotted land in the new world, and upon his return, Columbus was given a bonus.

\section{LEASING THREE SHIPS AND ONLY PAYING FOR ONE}

After agreeing to contribute 1,000,000 maravedis to Columbus's first voyage, the monarchs realized that they could only afford one of the three ships that Columbus needed to transport some 90 men. At this point, someone brought to the monarchs' attention that the city of Palos had not paid a penalty for an act of piracy they were accused of committing in the open seas. As penalty, the Spanish government required the city to provide two ships (Pinta and Nina) fully equipped with everything necessary for the voyage. Thus, even though the crown did not directly pay for the Pinta and Nina, the fair value of these leased ships, based on the customary charge of the day, will be estimated and attributed to the monarchs when computing their portion of the total contribution for the voyage.

Scholars disagree about how long Palos was required to provide the two vessels for. Some scholars claimed that Palos was responsible for providing two fully loaded vessels for twelve months (Dyson; 1991; Phillips and Phillips, 1992; Thacher, 1903; and Fusion, 1987). Christopher Columbus's son, Ferdinand, (Translated by Keen, 1959) states that Palos was only obligated to provide for two ships for three months. Davidson (1997) sets the time frame at two months. Because of the confusion, the actual time frame of the voyage will be used in estimating the value of the Palos ships. The actual voyage lasted approximately seven and months (August 3, 1492 to March 5, 1493). It is reasonable to believe that the men had to load and unload the ship before it could sail and/or be delivered back to the rightful owners upon its return. Thus one month for loading and unloading will be added to the seven-month voyage. The time period of eight months is consistent for the total voyage with Thacher (1903) who estimated the officers and crew were paid for eight months.

Thacher further notes that the traditional rate used to figure vessel costs, in those days, was approximately 120 maravedis per ton per month. He estimated that the Santa Maria, Pinta, and Nina weighed 120, 80, and 40 tons, respectively. Tirado (2001) indicates that the weights were approximately 100, 60, and 60 tons, respectively. Others estimated different tonnage capacity, but these two seem the most representative. Thacher and Tirado have the same overall average for the Pinta and Nina, and their average will be used to estimate the fair market value for these two ships. Since Thatcher's tonnage figures are higher for the Santa Maria than Tirado's, Thacher's higher tonnage will be used under the conservatism convention.

For some unexplained reason, while Thacher (1903) estimates wages and provisions for eight months, he used twelve months when determining the rental period for all three vessels. Thacher does note, without providing any explanation, that while the Santa Maria did not return, he was going to estimate the rental period for that vessel at one year.. He further notes that if the Santa Maria had returned with the other two ships, its rental period would not have been more than nine months, at most.

Thacher's monthly rental rate is composed of the custom-of-the-day rate of 120 maravedis per ton per month times twelve months. He then records the vessel rental rate at 172,800, 115,200, and 57,600 maravedis for the Santa Maria, Pinta, and the Nina, respectively, for a total of 345,600 maravedis. However, since the actual length of the voyage is closer to eight months than twelve, the numbers will be revised accordingly. Thus for purposes of preparing the pro-forma income statement, the vessel rates are reduced to 115, 200, 76,800 and 38,400 maravedis for the Santa Maria, Pinta, and the Nina, respectively, for a grand total of 230,400 maravedis. 
On or about Christmas Day, 1492, the Santa Maria crashed and sank. Columbus's daily log for this time period acknowledges that the owner of the vessel (Juan de la Casa) was on board at the time, yet it doesn't mentioned any sort of adjustment or dispute with respect to the rent for the Santa Maria (Fusion, 1987). Nor is there any record of any lawsuits being filed. Even though Thacher acknowledges that the Santa Maria sank after four plus months, he inexplicably used twelve months for determining this vessel's expense. As noted above, the total vessel rental of the Santa Maria was estimated at 120 maravedis per ton per month for eight months instead of twelve. Furthermore, since all of the wood from the Santa Maria was used to build a fort and a moat, the vessel rental for the Santa Maria will be divided into the two components: Vessel expenses and fort and moat. The value of the fort and moat will be calculated for two and one-half months out of the eight-month period. This amounts to 79,200 maravedis for the vessel expense for the Santa Maria and 36,000 maravedis for the fort and moat.

When Columbus returned on his second voyage, none of the men left behind from the first voyage were alive. Therefore, the fort and moat will be fully depreciated for the period of January 1, 1493 to March 5, 1493. Thus, for financial statement purposes, the fort and moat will be fully depreciated at 36,000 maravedis. An argument could be made that the fair market value of the boat should be used to determine the value of the fort and moat. This would be difficult: since the boat sank, its market value would have drastically declined after the accident and besides, 36,000 maravedis is not a large sum of money, even for that time.

Taviani (1974) places the value of the Palos vessels at 360,000 maravedis. Taviani arrived at his figures by estimating the total cost of the first voyage at 2,000,000 maravedis and then subtracted 1,140,000 for the crown's contribution and 500,000 maravedis for Columbus's supposed contribution in order to come up with the remaining balance of 360,000 maravedis. Davidson (1997) states that the historians Manzano and Varela assumed that the remaining 360,000 were for the rental of the two Palos vessels. Taviani's rate of 360,000 maravedis is at least twice as high as Thacher's initial figure of 172,800 maravedis which represents the value of the Palos vessels for twelve months. Davidson (1997) states the 360,000 maravedis comes from a rate of 3,000 maravedis per ton for twelve months times two ships at 60 tons each. On a monthly basis, this works out to 250 maravedis per ton, twice the daily rate assigned by Thacher, whose figures came from the financial documents of another Spanish voyage leased by the monarchs later in the year of 1493 .

Furthermore, if the figures above are valid, and the first voyage cost 2,000,000 maravedis, then based on Las Casas, Columbus contributed 500,000 maravedis, which would represent $25 \%$ of the total voyage expenses, which is not supported by the contract. Taviani does not provide documentation to support the 2,000,000 maravedis figure. Without providing any supporting details, Landstrom (1966) estimates the value of the Palos ships at 150,000 maravedis. Because Thacher provides the most support for his monthly rental figures of 120 maravedis per ton, and they are based on the custom of the day, his figures will be used for the eight month time period that the actual voyage occurred, including one month for loading and unloading. Thus, as previously noted, 115,200 maravedis will be used to represent the fair market value of the cost of the Palos vessels rental for eight months.

\section{WAGES, SALARIES, AND BONUSES}

It is believed that 90 men were on board the three ships when they sailed in 1492. Thacher (1903) lists crewmember by name and job title, and estimates their wages based on actual figures from a Spanish voyage chartered by the king and queen of Spain in 1493. According to Thacher, by using the 1493 wage figures (custom of the day), wages for eight-months are estimated at 268,000 maravedis for officers (excluding Columbus) and 252,000 maravedis for the sailors. The monthly wage rates used by Thacher have been supported by a number of sources including Phillips and Phillips (1992) as reasonable.

For the purpose of computing wages, it will be assumed that the families of the 39 men left behind when the Santa Maria sank would be paid at the regular rate until the time Columbus returned to Palos on March 5, 1493. Prior to the voyage, the crew was advanced four months' salary (Morison, 1956). Thus, as of March 5, 1493, for income statement purposes, the sailors and officers would have earned an additional four-months of wages. It is possible that the crown may have paid the families directly after the first four months had expired and before Columbus had returned. Since this matter is unknown, for the purposes of the pro-forma balance sheet, an account entitled 
"Receivables from monarchs" was created. For balance sheet purpose, it will be assumed that the families of the sailors did not receive any funds from the crown after four months of the trip had expired. As a result, current assets will equal current liabilities. If the crown had made any payments to the families after four months, those amounts would have reduced the receivable and liabilities accounts equally.

Some scholars (Phillips and Phillips, 1992) believe that Columbus was paid a wage of 140,000 maravedis as captain general of the fleet. But a review of the contract reveals no mention of a salary for Columbus as captain general. Based on the written contract, no salary will be estimated for Columbus since he was to receive a 10 percent commission on all of the treasures found and an additional 12.5 percent of the profits if he chose to invest up to 12.5 percent of the total costs of the first voyage. For the same reason, while Thacher (1903) lists Columbus as an officer, he did not include a wage for Columbus. This is further supported by Santangel's statement to the queen, that the crown would not be required to pay anything to Columbus until he, Columbus, actually found something of value. Thus Columbus was a joint venturer who would share in the profits of the first and subsequent voyages.

Upon his return Columbus showed the king and queen the gold, pearls, colorful birds, and other curiosities he had brought to Spain (Hale, 1891). Columbus was rewarded with a bonus from the king and queen in the amount 345,000 maravedis (Tirado, 2001). Dyson (1991) indicates that Columbus received a bonus of 10 ducats of gold worth approximately 335,000 maravedis and 10,000 maravedis was the first payment on his lifetime annuity because he was the first person to spot land (See Finder's Fee). Thus 335,000 maravedis will be used for the bonus figure in the pro-forma profit and loss statement.

\section{PROVISIONS}

Historical records indicate that the three ships (Santa Maria, Pinta, and Nina) were fully loaded just prior to the voyage. Though the three ships left Palos on August 3, 1492, they did not leave actually leave for the new world until Sept 7, 1492, because of rudder problems that occurred in the Canary Islands. They restocked in the Canaries and then again for the last time when they reached the Azores. Since actual accounting records do not exist, estimates based on the custom of the day will be utilized. Based on records for a crew that went to Africa around the time of Columbus's first voyage, food costs for sailors were estimated at 360 maravedis per month and double that for the officers (Thacher, 1903).

While these figures can't be verified, they can be scrutinized for reasonableness. In January 1492, the queen gave Columbus 20,000 maravedis to cover travel, clothing, and food expenses when he visited the court. Landstrom (1966) indicates that at that time a pig could be acquired for 400 maravedis, a cow for 2,000 maravedis, and a bushel of wheat for 49 maravedis. Thus, 360 maravedis per month for food for sailors appears reasonable. Thacher based his calculations on 90 people at 360 maravedis per month times 8 months $=250,560$ maravedis plus a bonus for 24 officers at 360 maravedis times $8=69,120$ maravedis for a total 319,680 maravedis. These figures also include the estimated food costs of the 39 men who were left behind because of the sinking of the Santa Maria.

\section{LAND HO: THE FINDERS' FEE CONTROVERSY}

Prior to the voyage, the crown promised to pay a 10,000 maravedis annuity for life to the first person who spotted land. Juan Rodrigo Borneo first discovered land, or so he thought (Pickering, 2000; and Phillips and Phillips, 1992). Unfortunately, when Borneo tried to claim his reward, Columbus argued, that he, Columbus, had seen the land the night before. The crown paid the annuity to Columbus and then to his common-law wife after his death. It is not known for how long this annuity was paid. For the purposes of this paper and because of the diminishing value over time, the present value of this annuity expense will be estimated at $4 \%$ for twenty-five years. It amounts to 156 , 220 maravedis. 


\section{TOTAL JOINT VENTURE CAPITAL CONTRIBUTED}

Based on the detailed cost analysis above, Exhibit 1 summarizes the key financial figures needed to compute the total amount of the financial contribution for Columbus's first voyage. This exhibit is divided into two sections: First, the monarch's contribution. is used to compute Columbus's 12.5 percent share, is presented, and then second, costs incurred by the monarchs that Columbus would probably not be held responsible for paying a 12.5 percent interest in are itemized. For example, the Crown voluntarily gave Columbus a bonus of 335,000 maravedis. It is unlikely that he would have to pay the Crown a $12.5 \%$ portion of a bonus to himself. The same appears to be true for the 10,000 maravedis annuity for the first person who spotted land in the new world. In Exhibit 1, the total estimated capital needed to fund the first voyage is estimated at 1,765,734 maravedis. Thus, this total is less than the 2,000,000 maravedis that a number of scholars claim is the estimated cost for the first voyage.

Exhibit 1

Spanish-Columbus Joint Venture

Summary of Total Contributions to Joint Venture in Maravedis:

\begin{tabular}{|l|c|}
\hline Estimated Cash Advanced by Crown & $1,000,000$ \\
\hline Estimated Value of Ships from Palos (8 months) & 115,200 \\
\hline Crown's Sharable Contribution & $1,115,200$ \\
\hline Columbus's 1/8th Estimated Contribution & 159,314 \\
\hline Subtotal Combined Sharable Contributions & $1,274,514$ \\
\hline Additional Crown Contribution not subject to Columbus 1/8th contribution & 156,220 \\
\hline Present Value of Finder's Fee Annuity & 335,000 \\
\hline Plus Crown's Bonus at end of Voyage & $1,765,734$ \\
\hline Total Estimated Pro-forma Contributions & \\
\hline
\end{tabular}

The total estimated capital of 1,765,734 maravedis (Exhibit 1) contributed to the joint venture will be used in determining the reasonableness of all of the expenses for the voyage. Exhibit 2 provides an analysis of the costs used in preparing the pro-forma income statement based on the analysis above, which generally supports the expenses listed by Thacher (1903). This study has found five differences that need to be made to Thacher's (1903) numbers in order to make them more accurate. The affect of these adjustments can be found in Exhibit 3 and include: 1. Present value of the Crowns finder's fee annuity: 2. Bonus given to Columbus; and 3. Division of the Santa Maria boat fee between vessel expenses and fort and moat costs. 4. Reduction of vessel rental figures from twelve months to eight months. 5. Due to the reduced vessel expenses from twelve to eight months, the miscellaneous account (furniture, powder, repairs and maintenance, etc) was increased accordingly, in order to balance.

Exhibit 2

Spanish-Columbus Joint Venture

Analysis of Pro-forma Costs in Maravedis

\begin{tabular}{|l|c|}
\hline Total funds to account for per Exhibit 1 & $\underline{\underline{1,765,734}}$ \\
\hline Wages for officers & 268,000 \\
\hline Wages for crew & 252,000 \\
\hline Finder's fee annuity & 156,220 \\
\hline Columbus's bonus & 335,000 \\
\hline Vessel leases - Palos & 115,200 \\
\hline Vessel Lease - Santa Maria & 79,200 \\
\hline Provisions for food & 319,680 \\
\hline Fort and Moat (depreciation) & 36,000 \\
\hline Repairs and maintenance (a residual balance) & 204,434 \\
\hline Total funds expended & $\underline{1,765,734}$ \\
\hline
\end{tabular}


Exhibit 3

Pro-forma Expense Statement Comparison Between Thacher and This Report Spanish-Columbus Joint Venture Development-Stage Company

Aug 3, 1492 - March 5, 1493

\begin{tabular}{|l|c|c|}
\hline & Thacher & Revised \\
\hline Operating Expenses (Maravedis) & & 319,680 \\
\hline & & 79,200 \\
\hline Provisions for Food & 319,680 & 115,200 \\
\hline Leased Boats - Santa Maria & 172,800 & 268,000 \\
\hline Leased Boats - Palos & 172,800 & 252,000 \\
\hline Salaries - Officers & 268,000 & 335,000 \\
\hline Salaries - Crew & 252,000 & 156,220 \\
\hline Columbus Bonus & & 204,434 \\
\hline Finders Fee & & 36,000 \\
\hline Repairs, equip, masc. & 155,062 & $1,765,734$ \\
\hline Fort/Moat (Depreciation) & & \\
\hline & & \\
\hline Total Operating Expenses & $1,340,042$ & \\
\hline
\end{tabular}

Thacher (1903) labeled one account as equipment, furniture, etc. Because of all of the repairs that were made during the voyage (replace rudder, change the sails for two ships before crossing the Atlantic, vessel leakage, etc.), the name of this account was renamed as miscellaneous. Its value was computed by subtracting all of the estimated expenses (Exhibit 2) from the capital contributions per Exhibit 2. Since Thacher's number (155,062 maravedis) was a residual amount and not directly calculated based on contract or custom of the day, the resulting figure per Exhibit 2 for miscellaneous expenses is estimated at 204,434 which is a residual after the adjustments are made. Thus the residual account (miscellaneous) account was increased from 155,062 maravedis to 204, 435 maravedis. Based on a comparison of the percentage of miscellaneous costs to total costs, the percentage increases for Thacher's numbers of 11.56 percent to 11.58 percent for the revised figures. The revised miscellaneous expense figure appears reasonable.

\section{REASONABLENESS OF THE TOTAL CAPITAL CONTRIBUTIONS}

In his biography of his father, Ferdinand Columbus states that his father's initial budget request was for 2,500,000 maravedis (Translated by Keen, 1959). Las Casas, a priest and a contemporary of Columbus, had access to Columbus's daily log of the first voyage claims that Columbus sought 2,000,000 maravedis. Reading between the lines, Columbus may have first asked for the moon and then starting reducing his requests. As noted by Las Casas (Translated by Collard, 1971) and Taviani (1974), the crown, through Santangel, eventually gave 1,000,000 maravedis to the joint venture. This is supported, as noted earlier, by Taviani (1974) and Landstrom (1996). Las Casas states that Columbus put up 500,000. This amount, if true, is significantly greater than allowed by the contract, which limits Columbus's contribution to 12.5 percent for which he could receive up to 12.5 percent of the profits.

It is unlikely that Columbus or any investor would contribute money that he or she would not be able to receive a return on investment. As shown in Exhibit 1, it is estimated that Columbus's 12.5 percent share is 159,314 maravedis. Determining that the fair market value of the two Palos boats at 115,200 maravedis makes the total shareable contribution between the crown and Columbus 1,274,514. Adding to this amount the present value of lifetime annuity and the bonus, the total capital contribution to the first voyage is 1,765,734 maravedis. Taviani (1974) estimates that the first voyage cost between 1,200,000 and 2,000,000 maravedis. Thus, the total of 1,765,734 maravedis appears reasonable based on Taviani's analysis. 


\section{REVENUES}

According to the contract with the monarchs, Columbus was supposed to receive a 10 percent commission on all commerce including pearls, precious stones, gold, silver, spices, and any other kind of merchandise bought and sold within the confines of the new admiralty. While Columbus received a special bonus of 335,000 maravedis upon his return, there is no record of his requesting or receiving any joint venture profits. A review of Columbus's daily log does not indicate that any serious buying and/or selling occurred in the normal course of business during the first voyage. What is noted is that throughout the daily log Columbus continually asks the natives and the chiefs where the gold could be found. What is noted is that inexpensive trinkets (beads, hawk-eyes, etc) were exchanged with the local natives for gold nose rings, bracelets, and gold dust purses. At other times, village chiefs gave Columbus gifts of thin plates of gold. However, the amount of gold brought back to Spain was so light that a court page could carry it around on a tray for all to see (Granzotto, 1985).

In addition, Columbus brought back exotic birds, jewelry, and other miscellaneous items (Dyson, 1991) including snake skins, spears, cotton, wool, spices, dyes, timber, etc. It is believed that these items were either given to Columbus as gifts or exchange for inexpensive beads or trinkets. Columbus notes in his log on October 12, 1492, that the inhabitants were so poor they did not even have any iron. These islanders traded parrots, cotton thread, spears, tobacco, and other items for glass beads and hawks-eyes for trinkets that Columbus referred to as being practically worthless (Fusion, 1987). Columbus was so concerned about his future commission that at one time he suggested that future vessels be required to dock at specified ports solely for the purpose of counting the merchandise so that Columbus would receive his commissions. Yet, the daily log does not support any significant discoveries of gold or any of the items mentioned in the contract with the Crown.

\section{PROFITABLE VENTURE OR DEVELOPMENT STAGE COMPANY?}

An argument can be made that Columbus's first voyage should be considered a development-state company. According to Dyckman, Davis, and Dukes (2001) startup cost represent those expenditures for a newly organized development-stage company prior to the generation of any significant revenues. Based on the normal customs of buying and selling, Columbus's daily log does not indicate that any serious business transactions ever occurred. A description of a development-stage company includes the fact that such companies spend considerable time raising capital, planning, and exploring for natural resources. Columbus spent six years in Spain seeking funding. The daily logs indicate that Columbus spent a significant portion of his time inquiring about and searching for gold. But no significant sources of gold were found, which may be the primary reason that he instructed those who did not return to Spain with him to continue to ask about and search for gold.

Therefore it seems that during the first voyage Columbus did not trade for profit but to create goodwill, hoping the natives would provide valuable information as to where gold could be located. The lack of a common language also made it very difficult for Columbus to obtain any reliable information about the whereabouts of gold. What items were brought back to Spain were used to support the idea that Columbus had found the "West Indies" and that Spain should return to the New World. Overall, what Columbus brought back to Spain appears to be insignificant enough to fall within the definition of a development stage company. Jane (1930) describes Columbus's first voyage as one of discovery, mainly the discovery of a trade route to Asia. While in North America, on his first voyage, Columbus spent most of his time searching for resources that he never found. Therefore, no revenues will be reported on the pro-forma income statement for this development-stage company. Due to the lack of success in finding significant amounts of gold, silver, and other minerals, all of the expenditures for the first voyage will be expensed to the income statement rather than capitalizing them as startup costs.

\section{THACHER'S NUMBERS NEED TO BE CHANGED}

Thacher (1903) appears to have provided the first and foremost detailed evaluation of the capital contributions and expenses estimated to have been incurred by Columbus in his first voyage. During the past 100 years Thacher's figures have been frequently cited. Thacher based most of his expense calculations on the customs of the day, which he derived from records of voyages made by contemporaries of Columbus. For example, he estimated 
the wages of the officers, sailors, vessel rental, and estimated cost of food provisions from details from voyages made under the Spanish flag in 1493 by another vessel leased by the Crown. Thacher's figures were not presented in the form of a balance sheet or income statement. Exhibit 3 provides for a comparison of Thacher's expenses to the ones resulting from this paper. Five differences are noted. As shown in Exhibit 3 Thacher ignored some expenses, such as the present value of the 10,000 maravedis annuity given to the first person to spot land in the new world. Thacher estimated the cost of renting the vessels for twelve months when the actual voyage was closer to eight months. Even though he noted that the Santa Maria sank and was turned into wood for the fort and moat, he did not divide the rental expense between vessel and fort and moat expenses. Thacher ignored considering Columbus's bonus as an expense of the first voyage. Lastly, because of the reduction in vessel expenses, the amount called repairs and maintenance was increased in order to balance to the amount contributed by the monarchs and Columbus. These additional items were included in the preparation of the pro-forma balance sheet and pro-forma income statement (Exhibit 3).

\section{COLUMBUS'S FIRST VOYAGE: PROFITABLE OR NOT?}

A pro-forma balance sheet at March 5, 1493 and pro-forma income statement from August 3, 1492 to March 5, 1493, have been prepared for this development-stage enterprise using the completed contracts method (Exhibit 4 and 5). Based on the above assumptions and following a three-step approach to determining which accounting number to use, it appears that Columbus's first voyage to the new world was unprofitable. The loss is not surprising as the voyage was a unique exploratory adventure for Columbus who was hoping to find a quick and cheap ocean route to Asia. Furthermore, Appendix A provides a pro-forma set of notes to the financial statement of this joint venture.

Exhibit 4

Pro-forma Balance Sheet

Spanish-Columbus Joint Venture Development Stage Company

March 5, 1493 (Maravedis)

\begin{tabular}{|l|l|l|c|}
\hline Receivable-monarchs & Accrued Salaries & 260,000 \\
\hline & & Finders Fee & 156,220 \\
\hline & & Accrued Boat Lease & 57,600 \\
\hline & & Accrued Bonus & 335,000 \\
\hline & & Total Liabilities & 808,820 \\
\hline & & & $1,606,420$ \\
\hline Building - Fort and Moat & & Capital - monarchs & 159,314 \\
\hline less Accumulated Depreciation & $-86,400$ & Capital - Columbus & $-1,765,734$ \\
\hline & & & $-0-$ \\
\hline & & - less loss for period & 808,820 \\
\hline Total Assets & & Total Ending Capital & \\
\hline
\end{tabular}


Exhibit 5

Pro-forma Income Statement

Spanish-Columbus Joint Venture Development-Stage Company

Aug 3, 1492 - March 5, 1493

\begin{tabular}{|l|c|c|c|}
\hline & & Reclass & Total \\
\hline Revenues & $-0-$ & & $-0-$ \\
\hline & & & \\
\hline Operating Expenses & & & 319,680 \\
\hline Provisions for Food & 319,680 & & 79,200 \\
\hline Leased Boats - Santa Maria & 115,200 & & 115,200 \\
\hline Leased Boats - Palos & 115,200 & & 268,000 \\
\hline Salaries - Officers & 268,000 & & 252,000 \\
\hline Salaries - Crew & 252,000 & & 335,000 \\
\hline Columbus Bonus & 335,000 & & 156,220 \\
\hline Finder's Fee & 156,220 & & 204,434 \\
\hline Repairs and Maintenance & 204,434 & & 36,000 \\
\hline Fort/Moat (Depreciation) & & & $1,765,734$ \\
\hline & & & $(1,765,734)$ \\
\hline Total Operating Expenses & $1,765,734$ & & \\
\hline
\end{tabular}

\section{LIMITATIONS}

After five hundred years have passed, the accuracy of assumptions used in the pro-forma financial statements becomes very difficult to determine. Many of the original accounting documents needed for this paper do not exist, so that estimates were used extensively. No profit and loss statement, if prepared at the time of the voyage, exists to this day. While the author believes the total amount contributed by the Spanish monarchs and Columbus appears reasonable, the sub-classification of expenses is mostly arbitrary. However, these sub-categories are not important when answering the question, did Columbus's first voyage show a profit or a loss? Determining profitability only requires two numbers: total revenues minus total expenses.

On October 12, 1492, Columbus states in his log that he took possession of the island (San Salvador) for the king and queen of Spain (Fusion, 1987). If valid, then the fair market value of this island should be included as a revenue and would easily make this first voyage profitable, but determining the fair market value of an island might prove difficult. Jane (1930) does note that the taking of land would have to wait for future missions. In fact, after Columbus's return, the Portuguese believed that everything that Columbus discovered was owned by the Portuguese. This issue would be settled by the Pope after Columbus's return. The Pope decided that the Portuguese-controlled lands up to 100 leagues west of the Azores and the Spanish anything west of that point.

This paper takes the position that taking possession of the land did not actually transfer title from the native inhabitants to Spain. The author believes the possession was a ceremonial taking, otherwise Columbus would most likely have informed the inhabitants that they now owed the crown rent and/or could purchase portions of land for their families. These acts did not occur. If the possession is viewed as a legal transfer of ownership of the island, valuing it would be most difficult, and any reasonable amount determined for the value of he land clearly turn the voyage from a loss to a profit. In addition, a review of the contract reveals no sharing of any islands that might be discovered. Thus, the island issue becomes one for the crown and not for the joint venture to decide.

\section{LIMITATIONS OF THE THREE-STEP MODEL}

Throughout this paper, the three-step decision-making model was used to evaluate the estimated capital contributions and estimated costs of this joint venture. Once the monarch's contribution for the joint venture was determined based on the contract, Columbus's portion was limited to 12.5 percent of the total shared costs, as per Part 
5 of the contract. If Columbus did indeed put up 500,000 maravedis, as Las Casas states, then using the contract for guidance may result in presenting a pro-forma financial statement that undervalues the amount of capital contributed. Since the total capital contributed is being used to determine the total expenses possible (Exhibit $1 \& 2$ ), this approach may end up showing less expenses than was actually incurred. Since most authorities agree that Columbus had silent partners who may have contributed to the voyage, these silent investors would have only contributed up to 12.5 percent of the total cost of the voyage in accordance to the contract with the royals. Thus, it is unlikely that they would have contributed more than 12.5 percent of the costs of the voyage if they would only be able to share in the profits, up to 12.5 percent.

As shown in Exhibit 1 Columbus's 12.5 percent portion is estimated at 159,314 maravedis. Thus the contract was used to reduce Las Casas's figure by 340, 686 maravedis. Furthermore, the contract was used to eliminate the 140,000 maravedis figure $(1,140,000-1,000,000)$ from being considered as either a wage to Columbus or interest expense for the joint venture. The custom of-the- day figures were used to determine wages, vessel expenses, and provisions. The actual costs could easily be higher or lower. For example, since this was an unusual voyage, it is possible the sailors and officers received more money than was customary at the time. It is not known for how many months in advance the Santa Maria was paid? Overall, while the three-step model was a good model to use in deciding between contradictory information, its use does not insure that the final figures used in this study are the ones that actually occurred. What the three-step model resulted in was insuring that the most conservative numbers were used.

\section{CONCLUSION}

It has been reported that Columbus may have been one of the best dealmakers in history. He really did not know where he was going, and even after four voyages, he never really got there. He convinced others to finance his adventure into the unknown, and when he got there, he did not know where he was. Yet, when he returned to Spain, he was able to obtain monies to finance a second trip with 17 ships and over 1200 people. It is noted that when planning the second voyage, Columbus did have some problems with the accountant Juan de Soria. So much so, that the sovereigns had to interfere (Landstrom, 1966). The sovereigns reminded Columbus that Soria was responsible for signing off on every invoice because he had to give account to the Inspector General of Taxes. At the same time, Soria received a letter saying that he had to make sure that Columbus left for the new world well satisfied. This story of Columbus's first voyage shows that venture capitalists don't need to see an initial profit in order to invest more capital for subsequent excursions. As long as people believe that more wealth is possible, somebody will finance another person's vision.

\section{REFERENCES}

1. $\quad$ Collard, Andree. Translated Bartolome de las Casas's work entitled History of the Indies. 1971.

2. $\quad$ Davidson, Miles. Columbus Then and Now: A Life Re-examined. 1997.

3. Dyckman, Thomas; David, Charles; Dukes, Roland. Intermediate Accounting. Fifth Edition Irwin McGrawHill 2001.

4. $\quad$ Dyson, John. Columbus For God, Gold, and Glory. Simon and Schuster 1991.

5. $\quad$ Fusion, Robert. The Log of Christopher Columbus. International Marine Publishing Co. 1987.

6. Granzotto, Gianni. Christopher Columbus. Doubleday \& Co., 1985.

7. Hale, Edward Everett. The Life of Christopher Columbus. 1891.

8. Helps, A. Help's Life of Columbus 1910.

9. Jane, Cecil. The Voyages of Christopher Columbus. 1930.

10. Jane, Cecil. The Journal of Christopher Columbus. 1960.

11. Kayserling, M. Christopher Columbus and the Participation of the Jews in the Spanish and Portuguese Discoveries. Hermon Press 1968.

12. Keen, Benjamin. Translated The Life of the Admiral Christopher Columbus by His Son Ferdinand. 1992.

13. Laufer, Joseph. Columbus Mythbusters. International Columbian Quincentenary Alliance. 1986.

14. Las Casas, Historia De Las Indias, Fondo de Cultura Económica, Mexico 1951.

15. Landstrom, Bjorn. Columbus: The Story of Don Cristobol Colon, Admiral of the Ocean. 1966. 
16. Martin, Josh. Management Review, Jun98, Vol. 87 Issue 6, 47-51.

17. Morison, Samuel Eliot. Christopher Columbus, Mariner. 1956.

18. Phillips, William \& Phillips, Carla. Voyage of Destiny American History Illustrated (pp 29-70). Oct. 1992.

19. Phillips, William \& Phillips, Carla. The Worlds of Christopher Columbus Cambridge University Press 1992.

20. Pickering, Keith. Examining the History, Navigation, and Landfall of Christopher Columbus. 2000.

21. Taviani, Paolo. Christopher Columbus The Grand Design. 1974.

22. Thacher, John Boyd. Christopher Columbus His Life, His Work, His Remains. Vol. 1. 1903.

23. Tirado, Thomas. Christopher Columbus Encarta Encyclopedia 2001.

24. Wolcott, John. Uncovering the Real Columbus. Aegina Press. 1992.

\section{APPENDIX A \\ Pro-forma Notes to Financial Statement}

\section{Background:}

The king and queen of Spain and Christopher Columbus founded this development-stage company in 1492. The joint venture was formally formed on April 17, 1492, when a contract was signed by the king and queen of Spain agreeing to the terms requested by the Chief Executive Officer, Christopher Columbus. One purpose of this company was to develop a trade route between Spain and Asia that would be faster than the current land route between the two. In addition, it was the purpose of this joint venture to search for and find pearls, precious stones, gold, silver, spices, and any other kind of merchandise deemed profitable. The company selected March 15th of each year to be the end of their fiscal year as it was the date that Columbus returned from the first voyage

\section{Executive Compensation:}

As a joint investor in this company, Christopher Columbus did not receive a salary as the officers and sailors did. According to a contract signed on April 17, 1492, Mr. Columbus was entitled to receive a $10 \%$ commission on all commerce, including pearls, precious stones, gold, silver, spices, and any other kind of merchandise bought and sold within the confines of the new admiralty. Furthermore, at his discretion, Columbus could invest up to $12.5 \%$ of the total expenditures of the trip and receive up to an additional $12.5 \%$ of the profits. No commissions or profits were paid. At the discretion of the king and queen of Spain, a bonus of 335,000 maravedis was paid.

\section{Accounting Method:}

In accordance with the Spanish Accounting Standards Board (SASB) the following accounting methods were used. The joint venture used the completed contracts method for preparation of its annual statement. The joint venture used the accrual basis of accounting, which records revenues when earned and expenses when incurred.

In the normal course of business, the straight-line method of depreciation was used. Inventory will follow the FIFO principle of first in-first out.

\section{Development Stage Company:}

The first voyage was primarily for the purpose of exploring and looking for a potential trade route to China and for identifying potential sources of gold, silver, and other minerals. Because no real measurable sales activities occurred on this voyage, this financial statement has been prepared in accordance with the rules established by SASB for Development Stage Companies.

\section{Leases And Contingency:}

The joint venture leased three vessels (Santa Maria, Pinta, and the Nina). According with SASB, these are operating leases, as the first exploratory voyage was intended to last less than one year. During the first voyage, at the end of December, 1492, the Santa Maria hit some rocks and became unrepairable. Because the two remaining ships 
were not able to carry all 90 men, 39 men remained behind in the new world. The wood from the ship was used to build a fort and a moat for these men. No additional liability beyond paying the lease payments for the duration of the first voyage was accrued. Two and one-half months of lease payments for the Santa Maria was reclassified to fixed assets since it was used to build a fort instead of operating a ship. The fort was fully depreciated, as the company had no long-term plans for the facility.

\section{Accounts Receivable:}

At the beginning of the voyage, the crew was paid four months wages in advance. It is assumed that the owner of the Santa Maria was paid four months in advance because Davidson (1997) notes that it was the tradition at the time to prepay the owners for the use of their vessel. There is no evidence to the contrary that Columbus and the others thought the trip would last longer than four months. Because the voyage lasted eight months, four months of accruals are made for the officer and crew's wages. The same for the rental of the Santa Maria. It is noted that it is possible that after four months the families of the 90 men were paid a monthly stipend equal to their agreed upon wages until Columbus returned. Thus, if paid, the receivables and accrued liabilities would be reduced by the same amount.

\section{NOTES}

